\title{
Technical Education - The Key to Sustainable Technological Development
}

\author{
Odo J.U. ${ }^{1}$, Okafor W.C., ${ }^{2 *}$, Odo A.L. ${ }^{3}$, Ejikeugwu L.N. ${ }^{4}$, Ugwuoke C.N. ${ }^{5}$ \\ ${ }^{1}$ Department of Metallurgical and Materials Engineering, Nnamdi Azikiwe University, Nigeria \\ ${ }^{2}$ Department of Mechanical Engineering, Chukwuemeka Odumegwu Ojukwu University, Uli, Nigeria \\ ${ }^{3}$ Administrative Department, Scientific Equipment Development Institute, Nigeria \\ ${ }^{4}$ Advance Manufacturing (Machine Design \& Building) Unit, Scientific Equipment Development Institute, Nigeria \\ ${ }^{5}$ Metallurgical and Materials Research and Development Unit, Scientific Equipment Development Institute, Nigeria
}

Copyright $\mathrm{O} 2017$ by authors, all rights reserved. Authors agree that this article remains permanently open access under the terms of the Creative Commons Attribution License 4.0 International License

\begin{abstract}
Technical education has been identified as one of the most effective human resource development that needs to be embraced for rapid industrialization and sustainable technological development of any nation. Technical education has been an integral part of national development in many societies because of its impact on productivity and economic development. This paper discusses the dearth of skilled technical manpower in Nigeria and its effect on the technological development of the nation. It advocates for a comprehensive revitalization of technical education in Nigeria to promote workforce partnership needed to develop innovative approaches or replicate models that operationally demonstrate has demand technological the society needs. Efforts and ways by both by the government and individuals to train and produce the required manpower for the achievement of vision 20, 2020 objectives were also suggested by the authors.
\end{abstract}

Keywords Technical Education, Sustainable Development, Economic Development, Skilled Manpower, Industrialization, Technological Development

\section{Introduction}

Technical education is education that prepares people for specific trades, craft, technical or a professional position in engineering, accountancy, nursing, medicine, architecture, pharmacy, law etc. Craft vocations are usually based on manual or practical activities, traditionally non-academic related to a specific trade, occupation, or vocation. It is sometimes referred to as vocational education as the trainee directly develops expertise in a particular group of techniques $[1,2 \& 3]$.

Technical education may be classified as teaching procedural knowledge. This can be contrasted with declarative knowledge as used in education in a usually broader scientific field, which might concentrate on theory and abstract conceptual knowledge, characteristic of tertiary education. Technical education can be at the secondary, post-secondary level, further education levels and can interact with the apprenticeship system. Increasingly technical education can be recognized in terms of recognition of prior learning and partial academic credit towards tertiary (e.g. at a university) as credit, however, it is rarely considered in its own form to fall under traditional definition of higher education.

Technical education is related to age-old apprenticeship system of learning. Apprenticeships are designed for many levels of work, from manual trades to high knowledge work. However as the labour market becomes more specialized and economies demand higher levels of skills, government and businesses are increasingly investing in the future of technical education though publicly funded training organization and subsidized apprenticeship or traineeship initiatives for business. At post-secondary level, technical education is typically provided by an institute of technology polytechnics, university or by a local community college.

Technical education has diversified over the $20^{\text {th }}$ century and now exists in industries such as retail tourism, information technology, funeral service and cottage interties [4 \& 5]. Technical and vocational education (TVE) has been an integral part of national development strategies in many societies because of its impact on productivity and economic development. Despite its contributions, the leaders of Nigeria have not given this aspect of education the attention it deserves. This is one of the reasons for the Nations underdevelopment. This paper discusses technical education as "the key to sustainable technological development".

\subsection{Technical Education and Technological and National Development}

a Technical education "is a planned programme of courses and learning that begins with exploration of 
career potions, supports basic academic and life skills, and enables achievement of high academic standards leadership, preparation for industry defined work, and advanced and continuing education;

b Technical and vocational education and training "prepares learners for careers that are based in manual or practical activities, traditionally non-academic and totally related to a specific occupation of vocation in other words, "it is an education designed to develop occupational skills".

c Vocational and technical education gives individuals the skills to live and work is a productive citizen in a global society.

\section{History of Technical Education}

The provision of vocational and technical schools has a long history. Before the industrial revolution (1750-1830) home and the "apprenticeship system" were principal sources of vocational education but societies were later forced by the decline of handwork and specialization of occupational functions to develop institutions of vocational education [6].

Manual training that involves general instructions in the use of hand tools was said to have developed initially in Scandinavia (c. 1866). However, vocational education became popular in the elementary schools in the United States after 1880 and developed into course in industrial training, book keeping, stenography and skilled commercials works in both public and private institution.

The United States of America is not the only society that appreciates skills acquired through vocational and technical education, the Dutch school system is said to pay attention to "high standards in mathematics and the provision of vocational education at ages 14-16 for a third of all pupils, and widespread vocational education at $16+[7 \& 8]$.

Secondary (high) school in many other development concerns nations have vocational centers that offer vocational training for lifelong trade together with general academic studies. For instance, India and the "Asian Tiger" could not have become what they are without massive investment in technical education. However, because of recent changes in the world economy many vocational and technical schools have shifted emphasis to training in the computers and information technology [7\& 9].

While technical and vocational education has continued to thrive in many societies, Nigeria has neglected this aspect of education. In Nigeria, technology education was preciously not seen as fundamental for national development, or for the economic development, but for the schools dropouts and other social and political development within the nation and for individuals. However, [10] had argued that technology education is linked to human resources development and that this has an impact on more than just economic growth but also an impact on the wider development of individuals and societies.
The neglect of technical education is socially and economically injurious because it is robbing the nation the contribution the graduates would make on national development. Consequently, the society lacks skilled technicians: bricklayers, carpenters, painters, auto-mechanics, laboratory and pharmacy technicians, electrically electronic technicians, and skilled vocational nurses, etc.

\section{Technical Education and Sustainable Development}

The development of any nation hinges on the socials and economic contributions of her citizens Education, vocational and technical training play a major role at promoting community and national development [11]. Vocational and technical education promotes and facilitates the acquisition of applied skills and basic scientific knowledge. It is planned programme of course and learning experiences that begin with the exploration of career options, supports basic academic and life skills and enables the achievement of high academic standards, leadership, preparation for industry and continuing education [5].

It cannot be over emphasized that technical education is the engine of economic growth. No nation can fight a war without the army. In the same vein, Nigeria cannot develop without well-equipped technical and vocational institutions. Unfortunately, Nigeria does not seem to give vocational and technical education the attention it deserves. Technical Education has been described as the "missing link" in Nigeria development policy [12]. Because of poor training and ineffective institutions, Nigeria suffers from low productivity in all aspects of economic and technological endeavours. This appears to be one of the reasons for rising rate of unemployment and poverty in the society.

The growing problem of unemployment in the country has contributed largely in the worsening problem of poverty among the populace. This is because the youths and graduates from tertiary institutions are not equipped with adequate skills that will enable them to exploit the natural resources that abound in Nigeria. Scholars like [13], posits that unemployment leads to frustration and disillusionment which may result in crime or drug abuse in a futile attempt to escape from humiliation and insults associated with poverty and lack. The problem of unemployment, he further stated has worsened as millions of school leavers and graduates of tertiary institutions are not gainfully employed. The reason is that they lack the necessary skills that would enable them to be self-employed and effectively function in today's world of work. However, [3] in stressing the importance of technical education asserts that technical and vocational education in a comprehensive term refer to those aspects of education process in evolving the acquisition of practical skills, attitude, understanding and knowledge relating to occupations in various sectors of economic and social life. 
Technical education if given the required attentions needed, it can alone transform the nation into one of the leading country in ICT and economic development because of much benefits embodied in it. Some of these benefits include:

a Creation of employment opportunities: The issue of unemployment will remain a problem to Nigeria for many years if people are not trained/ educated on how to be self-employed. Technical education is the only sure tool of fighting the rate of unemployment in the country. This can be achieved through educating the people on how to use their brain, body and hands to engage themselves in different productive activities to earn good money and live fulfilled life.

b Income/revenue generation: Technical education has its ways of boastings the economy of the nation through empowering the people technically in one field or the other. For instance, if a man has been trained to manufacture/produce car parts at the end of the day, he will pay his tax to the government and also have some left for his livelihood and maintenance of his household.

c Enhancing people's standard of living/poverty reduction: Technical education improves people lives and living standard through training the youths in useful skills, engaging them in productive works, generation of income and reduction of security votes by the government, creation of employment opportunities thereby increasing the economic and social standards of the citizens.

d Nation's self-independence: If the concept of technical education is properly employed with all its relevance benefits in no distant time Nigeria will not only be independent economically and technologically but will also be among the leading country in ICT and export of goods and services in the world and several ugly and embarrassing situations will be addressed.

\section{Challenges of Technical Education in Nigeria}

It is obvious despite the numerous benefits that come with technical education in national development; we are still having problems in bringing it to lime light as a result of poor policies and corrupt leaders. As a developing nation, if we can channel our efforts in addressing this issue then we can believe that he sky will be our limit. The challenges militating the training of technical education personnel, technicians and technologists are many but a few of the major ones are highlighted below.

a Poor funding: The funding of technical and vocational education programme is very poor and inadequate. The success and developmental advancement in technical and vocational education which have been actualized over the years has been frustrated as a result of poor funding [14]. Financial sustainability facilitates the development of knowledge which requires innovative measures so as to ensure that the public vocational and technical education colleges/institutions are not deprived of the much needed resources for their future expansion [8].

b Acute shortage of vocational technical teachers: Many of the trained technical teachers because of the neglect on them as regards remuneration and incentives have moved from schools to the industries and sometimes to developed countries where they get better pay for their services. Some teachers and students who leave the country to acquire more knowledge and skills at the end of their training refuse to return to the country because of poor attention to technical teachers by the government and the public. Also some skilled professionals abandon the practice of technical education in favour of other more lucrative economic activities and political appointments which are not related to their training.

c Inconsistent Government Policy on Technical and Vocational Education: Inconsistency in the formulation and implementation of technical and vocational education policies has been a major setback to the advancement of technical and vocational education. Lack of follow-up and continuity in government and her ministers or commissioners of education as a result of selfishness and corruption has been one of the key factors facing technical education and national development.

d Lack of Adequate Training Facilities and Equipment: Most technical colleges in Nigeria do not have laboratories or workshop space let alone useable equipment and facilities. Where they exist, they are grossly in adequate and obsolete, as the laboratories only have the items or equipment that were provided when the colleges were established. Most technical colleges cannot boast of adequate functional workshops and laboratories even when the teachers may be ready to teach the students in spite of the poor remuneration. There are some cases where technical equipment/machines were supplied but no workshop to install the equipment. This certainly will lead to frustration on the part of the technical college teachers, students and parents.

e Staff Training, Re-training and Retention: Most technical teachers have poor training background owning to the problem encountered during the training process. Most technical teachers in our technical colleges have never since their practice gone for re-training program in order to keep abreast with the ever-dynamic technical innovations associated with the ever-ending needs of the society. The training of technical teachers is ordinarily a continuous exercise to ensure consistent improvement in the quality of their 
output. This training can be acquired locally or otherwise. Usually local training is cheaper but more strenuous because of inadequate facilities and literature overseas training requires a lot of foreign exchange but the enabling environment help to achieve success in record time. However, overtimes it has always been difficult to get the trainees back to Nigeria after the completion of their study.

$f$ The Curriculum of Technical Education: The curriculum of a subject with practical content is generally organized into an average of $67 \%$ for the theoretical classes and 33\% for laboratory or workshop. Students also use the laboratory to develop case examples on their own time. Again, [15] noted that one of the issues confronting the design of appropriate curriculum for technical education is preparing students for the shift from florist to Information and Communication Technology (ICT) paradigm in technical practice. The curriculum for technical education in Nigeria has remained under the focus of the colonial masters, i.e., foreign model which has evolved under ideal condition (staff, equipment, infrastructure, training opportunities, etc), that are not easily duplicated in development countries. The low pace of industrialization and technological growth in Nigeria can be attributed to the widening gap between science and technology as a result of the inability of technical education program to adequately utilize the scientific-ideas to promote technology.

g Mal-administration: Most of the problems encountered in the field of vocational and technical education programs in general are grossly caused by poor planning, administration and management [16], noted that by far, the greatest obstacle to a rapid acquisition of technology in poor countries could be traced to the types and quality of management system prevalent in these countries, whereas in developed counties all managers of private and public sectors are technically trained. Technical managers in developing countries are essentially managers who have grown without any technical background and training. It is quite evident that in Nigeria those who know little or nothing about ethics of vocational and technical education programs are meant to man such establishment. For instance most times you may find ministers and commissioners of education as lawyers, accountants, priests, medical doctors, engineers, etc. This has a lot of negative tendencies to our development program/initiatives.

Other problems associated with vocational and technical education in Nigeria may include; gross neglect, lack of well-equipped library for research work/project, poor professional, personal and public images lack of adequate motivation, decline in student's enrolment, lack of use of modern technology/information technology for teaching and learning, use of poorly qualified technical staff, unemployment, lack of entrepreneurship education, lack of adequate security/security needs, etc.

\section{Revitalizing of Technical Education}

This is procurable via:

a Mandatory Continuing Professional Development (MCPD): There is provision in the National Policy on Education (NPE) $4^{\text {th }}$ Edition [17] relating to the Mandatory Continuing Professional Development (MCPD). An individual shall be able to choose between continuing full time study, combining work with study or embarking on full time employment without excluding the prospect of resuming studies later on. Professional development avails teachers the opportunity to develop, update and demonstrate their profound competence against set standards. This is absolutely essential for the strength, vibrancy, updating and future of the teacher profession.

b Adequate Funding: The political will and national co-operation in terms of funding is fundamental and non-negotiable to revitalization of technical education in Nigeria which is the major obstacle of the development of technology, industrial and economic growth of Nigeria. Effective teaching and learning of technical and vocational education requires adequate funding to build more new classrooms, laboratories/workshops, provide facilities and equipment/machines/ tools.

c Use of Information Technology for Teaching and Learning: Information technology (IT) is affecting education in revolutionary ways and the momentum is irreversible. Information and Communication Technology has to be incorporated as part of teaching and learning tools in technical and vocational institutions to harness the advantages of educational delivery. The visual library as a platform for sharing knowledge is aimed at rejuvenating Nigerian schools through the provision of current textbooks, journals and other information sources using digital technology.

d Retraining of Technical Education Teachers: The generality of the people are becoming aware of the economic value/benefit of technical education as the avenue for turning the economy and technology around. According to [15], the Federal Government's recognition of vocational and technical education as a powerful tool for technological development has created public awareness of the indispensability of this aspect of education. This is seen through the establishment and expansion of more institutions of vocational and technical education to provide needed manpower in the sector. The technological teachers training programmes (TTTP) introduced by the Federal 
Ministry of Education is a deliberate attempt to brighten the future of technical and vocational college teachers by sponsoring them to higher heights of the ladder in their profession. Seminars, conferences, workshops, etc should be organized for technical teachers periodically so as to be acquainted with the ever-changing technological innovations.

e Campaign towards Vocational and Technical Training: Vocational and technical education has been neglected for a long time because of the negative perception of those who should project and nurture it to maturity. The negative attitude of many people, parents and students to vocational and technical education should be hanged by all and sundry. The government, educationist, teachers and students alike should carry out a campaign or orientation program towards enlightening the general public/citizens on the need for their children to be vocationally and technically oriented in light of the prevailing economic circumstances of the nation. Unemployment and poverty level are on the increase. Technical education will aim to cater for all and sundry, through their manipulative skills acquired.

f Professional Diploma in Education: All teachers in educational institutions shall be professionally trained. A one year professional diploma in education has been suggested for all teachers in educational institutions. Former Technical Registration Council of Nigeria (TRCN) now National Board for Technical Education (NBTE) has been mandated to structure the diploma program to equip technical teachers without teaching qualifications for effective performance of their duties. This will facilitate the extension of the best professional development programs to the teachers.

g Encouragement of Research, Inventions and Innovation: Everyone who cherish genuine growth and sustainable development, government, private and corporate organizations, non-governmental organizations and individuals should as a matter of due responsibility encourage and finance research activities/programs, skills acquisition, inventions, innovations and mass production of invented products. This will help the development of interest in technical and vocational education which is the engine for skills acquisition, creativity, research, invention innovation and entrepreneurship that promote technological and economic activities for sustainable development of the nation.

$\mathrm{h}$ Incentives to Teachers and Students of Technical and Vocational Education: Technical college teachers are most often subjected to deplorable conditions. Hardly are they found in furnished offices, instead they are put in large staff rooms, a times with students type of lockers or desks and chairs, whereas their counterparts in other sectors could have executive air-conditioned offices, private secretary or even messengers, cars and reserved parking spaces. They could belong to prestigious clubs and associations because of better salaries. Salaries of technical education teachers should be increased to certain level or equal to their counterparts in industries and other sectors to boast their moral. Also other incentives such hazard allowance, overtime, workshop/seminar/conference sponsorship should be given to them for encouragement and support. Moreover, students of technical colleges should be given scholarship by the government and the philanthropists, free medical care; free safely wears, free textbooks and free access to e-library as an encouragement or incentives.

\section{Conclusions}

Technical education holds the key to sustainable national development. Technical education programmes in Nigeria has not attained the maximum performance of its potential roles of national economic and technological development. The neglect by the government, private and corporate organizations outlook of the society and other variables hinder its development and contribution to social and economic growth. Nigeria cannot develop without well-equipped technical and vocational institutions. In fact, according to [18], it is the missing link in Nigeria's development policy. Because of poor training and ineffective technical institutions, Nigeria suffers from low productivity.

However, the progress of any society lies in the productivity of its citizens. Higher productivity gives a nation advantage of economies of scale and lowers the costs of production and prices of goods and services. It is technical education that can give the technological skills required to keep pace with the speed of global transformation technological and economically. This cannot be achieved, except through a complete revitalization of technical education, in Nigeria, with the emergence of strong and vibrant activities that are developmental and technological oriented.

Nigeria should begin now to take very seriously investment in technical education and skill acquisition as no nation can compete effectively in the global market with poorly educated and skilled manpower. The leading factors of production in the emerging global economy are said to be technology, knowledge, creativity and innovation.

Finally, the nation's vision 20, 2020, the Seven-Point Agenda and the transformation Agenda - President Goodluck Jonathan's ROADMAP to Nigeria's development will remain a paper tiger without the turn around to technical and vocational education.

\section{Recommendation}

In view of the problems highlighted in this paper, the 
authors hereby recommend that:

i. The Federal, State and Local Governments should compulsorily make vocational and technical education subject foundation programs institutions across the country. This is to enable all individuals the opportunity to understand and appreciate the important of this laudable program to the development of every individual and the nation.

ii. The curricula of technical education should meet the needs of modern industries and should be at par with international standards.

iii. Emphasis should be made on the practical aspect of technical and vocational education which will help to produce productive members of the nation's labour force that will be self-reliant or employable in industry or company.

iv. Government should provide adequate facilities to technical college workshops and laboratories using current strategies identified to ensure acquisition of relevant skills, knowledge and experience that are relevant to the growth of the country.

v. Non-governmental organizations (NGOs), industrialists, philanthropists, parents-teachers association (PTA) and community based organizations (CBOs) should be sought for support in supplying/provision of relevant facilities, equipments/machines as obtained in some nations.

vi. Enough funds should be made available by the government to technical education institutions from the Education Trust Fund for the procurement of tools, equipment, training materials and infrastructural facilities the allocation and release of such funds should be properly monitored and utilized to avoid leakage of funds.

vii. Quality and modernization focused technical education. Technical education structure requires sound management skills based on innovation, adaptability and effectiveness. Continuous professional development schemes and tools should be established throughout the system for re-training of staff in all facets of technical education. More modern learning aids such as computers, internet, website facilities, overhead projectors, firms on technological development/training, etc, should be provided in schools. E-learning and long distance training, geared to technological advancement, professionalism in the globalization era should be developed to accelerate the upgrading of skills and transfer of knowledge among the staff and students.

viii. Finally, awareness of the importance of technical education should be increased, because the development and growth of technology and economic activities for the nation's advancement depends on technical education. The media should be used to disseminate information about the value of technical and vocational education to the public. This would definitely help in improving Nigerian's culture and attitude to technical education and national development.

\section{REFERENCES}

[1] Okoro, O.M. (1993). Principles and Methods of Vocational and Technical Education. Nsukka University Trust Publishers, Nigeria.

[2] Uwaifo, V.O. (2005). Vocational Education and General Education. Conflict or converge, Nigerian Journal of Educational Research 4(1). Institute of Education, Ambrose Ali University Ekpoma, Nigeria.

[3] Okorie, J.U. (2001). Vocational Industrial Education League of Researchers, in Nigeria, Owerri.

[4] Alwasilah, A. Chaedar (2009). "Vocational education must provide students with life skills. The Jakarta post.

[5] Ozoemena, S.A. (2013). Vocational and Technical Education: A Tool for Sustainable Development in Nigeria, Journal of Education and Practice Vol. 4 No. 25.

[6] Duffy, V.F. (1967), E.d. Essay on Apprenticship.

[7] Bart Van Ark (1992). "Vocational Education and Productivity in the Netherlands and Britain" National Institute of Economic Review.

[8] Amoor, S.S. (2008). The challenges of Vocational and Technical Education Programme in Nigerian Universities. Retrieved 11th March, 2015. http://www.google.com.

[9] Dike, V.E. (2003). "Vocational Education" Missing link in Nigeria's Development Policy - Online http://www.nigeianvillage.com/articles/victordike. $\mathrm{P}=2 \mathrm{html}$.

[10] Hallack, J. (1990). Investing in the future, seeing educational priority in developing world, UNESCO, Paris.

[11] Oguntuyi, A.N. (2013). A Viable Vocational Technical Education Curriculum: A Tool for Economic and Technology Development. Scholarly Journal of Education, 2(2), 22 - 26.

[12] Dike, V.E. (2005). "Vocational Education" Impacts in Nigeria's Development Policy - Online http://www.nigeianvillage.com/articles/victordike. $\mathrm{P}=2 \mathrm{html}$.

[13] Olaitan, S.O. (1996). Vocational Technical Education in Nigeria (Issues and Analysis). Noble Graphic Press, Onitsha.

[14] UNESCO, (2004). Technical and Vocational Education Training for the 21 st Century, France.

[15] Olunlogo, V.O.S. (2002). The Challenges of Globalization for the design of Technical Curriculum in Developing Countries. First Edition University of Lagos Press, 217-237.

[16] Madu, R.O. (1980). Technology Acqusition in Developing Countries: Challenges Nigerian Journal of Technical Education, Issue 1 Volume 2 pp 17 - 76. 
[17] NPE (2004). National Policy on Education, Lagos Nigeria.

[18] Edigin, J.E.O. (2000). Vocational and Technical Education in
Nigeria, Issues, Problems and Prospects. Vocational and Technical Education, Postgraduate Seminar Trainee Workshop, Benin City, Nigeria. 